\title{
PENGARUH PENGUASAAN PRINSIP DAN UNSUR SENI RUPA TERHADAP HASIL BELAJAR MENGGAMBAR FLORA DI SMP SWASTA AL-ULUM MEDAN
}

\author{
Juwita Sari $^{1^{*}}$, Nels on Tarigan ${ }^{2 *}$, Fuad Erdansyah ${ }^{3 *}$, Sumarsono $^{4 *}$ \\ Program Studi Pendidikan Seni Rupa Jurusan Seni Rupa Fakultas Bahasa dan Seni \\ Universitas Negeri Medan \\ Jl. Willem Iskandar Pasar V Medan Estate, Kec, Percut Sei Tuan, Kab. Deli Serdang, Kode Pos 20371 \\ Sumatera Utara. Indonesia \\ Email: jujupj499@gmail.com
}

\begin{abstract}
Abstrak
Penelitian ini bertujuan untuk membuktikan pengaruh penguasaan prinsip dan unsur seni rupa terhadap hasil belajar menggambar flora. Objek yang digambar adalah pohon. Adapun populasi dalam penelitian ini yaitu kelas VII SMP Swasta AL-ULUM Medan dengan sampel 3 karya sis wa dengan teknik Cluster Random Sampling. Sampel yang akan diambil dengan menggunakan Pretest dan Posttest ag ardapat terlihat perbedaan dengan penguasaan prinsip dan unsur seni rupa. Penelitian ini menggunakan metode deskriptif kualitatif dengan mendeskripsikan gambaran yang diteliti dan dinilai berdasarkan prinsip dan unsur seni rupa yang telah ditentukan yaitu garis, bentuk, warna, gelap terang, proporsi dan karakter objek. Hasil temuan penelitian ini menunjukkan bahwa secara keseluruhan karya yang dihasilkan berdasarkan prinsip dan unsur seni rupa terdapat pengaruh yang cukup signifikan dilihat dari hasil karya Pretest dan Posttest.
\end{abstract}

Kata Kunci: prinsip, unsur, seni rupa.

\begin{abstract}
This study aims to prove the influence ofmastery of the principles and elements of fine arts on flora learning outcomes. The objectdrawn is a tree. The population in this study is grade VII Medan ALULUM Junior High School with a sample of 3 student work using the Cluster Random Sampling technique. Samples to be taken using Pretest and Posttest so that differences can be seen with the mastery of the principles and elements offine arts. This study uses a qualitative descriptive methodby describing the images studied and assessed based on predetermined fine art principles and elements, namely lines, shapes, colors, light darkness, proportions and character of objects. The findings of this study indicate that overall the work produced is based on the principles and elements of art there is a significant influence seen from the work of Pretest and Posttest.
\end{abstract}

Keywords: principles, elements, fine art.

\section{PENDAHULUAN}

Belajar merupakan tugas utama setiap siswa, namun tidak semuanya dapat mengatur belajar dengan baik terkhususnya dalam mengatur waktu belajar setiap mata pelajaran yang bermacam-macam. Murid akan dituntut untuk menghadapi serta memahami setiap mata pelajaran deng an baik, hal itu pula yang dialami siswa kelas VII SMP Swasta AL-ULUM Medan. Salah satunyayaitu mata pelajaran Seni Budaya yang merupakan mata pelajaran yang penting bagi siswa untuk meningkatkan sensitivitas siswa dalam kemampuan mengekspresikan dan kemampuan mengapresiasi keindahan dan harmoni.

Mata pelajaran Seni Budaya beralokasi waktu $3 \times 45$ menit yang biasa diajarkan di sekolah menengah pertama dan itu sudah termasuk dalam bidang seni rupa, seni musik dan seni tari. Ketiganya sama penting, hanya saja yang akan dibahas dalam penelitian ini adalah seni rupa. Dimana seni rupa memiliki peran yang sangat penting dalam kehidupan manusia. Selain sebagai sarana menuangkan ide dan kreativitas, seni rupa juga membantu manusia untuk memahami segala yang dapat dilihatnya sehingga memberi suatu rasa, makna serta keindahan. Senirupa memiliki wujud pasti dan tetap yakni dengan memanfaatkan unsur rupa sebagai salah satu wujud yang diklasifikasikan ke dalam bentuk gambar, lukis, patung, grafis, kerajinan tangan atau kriya dan multimedia.

Kompetensi dasar yang harus dicapai dibidang seni rupa adalah meliputi kemampuan memahami dan berkarya lukis, kemampuan memahami dan membuat 


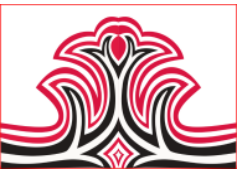

patung, kemampuan memahami dan berkarya grafis, kemampuan memahami dan membuat kerajinan tangan, serta kemampuan memahami dan berkarya atau membuat sarana multimedia. Dari keseluruhan kompetensi ini, menggambar merupakan dasar dari semuanya. Sadar akan pentingnya keterampilan menggambar dalam seni rupa, maka belajar menggambar sudah selayaknya menjadi kebutuhan dan sekaligus menjadi kegiatan yang menyenangkan.

Dalam keterampilan menggambar yang menjadi das ar karya gambar menjadi ideal adalah dengan menerapkan prinsip dan unsur seni rupa. Dimana dalam prinsip-prinsip seni rupa meliputi kesatuan, keseimbangan, irama, penekanan, proporsi, dan keselaras an. Sedangkan unsur seni rupa meliputi titik, garis, bidang, bentuk, ruang, warna, teks tur, dan gelap terang. Dari kes eluruhan itu siswa dituntut untuk dapat menerapkannya pada saat menggambar suatu objek agar dapat menghasilkan karya yang baik dan lebih ideal.

Berdasarkan pengamatan langsung penulis, pembelajaran senibudaya di SMP Swasta AL-ULUM Medan dilakukan dengan metode ceramah. Materi pembelajaran menggambar flora sudah pernah disampaikan sesuai dengan kurikulum seni budaya SLTP, namun hanya berupa pengenalan dan pemberian tugas saja, sehingga siswa belajar tidak sampai secara mendalamdengan menerapkan prinsip dan unsur seni rupa. Terlebih dalam proses belajar menggambar ada baiknya jika metode y ang digunakan tidak hanya ceramah, yaitu juga dengan metode demons trasi. Hal ini akan berpengaruh terhadap s is wa untuk lebih mudah memahami dan dapat lebih mudah untuk mempraktekan.

\section{KAJIAN TEORI}

\section{Belajar dan Hasil Belajar}

Menurut Ahmad (2013: 04) "belajar adalah suatu aktivitas yang dilakukan seseorang dengan sengaja dalam keadaan sadar untuk memperoleh suatu konsep, pemahaman, atau pengetahuan baru sehingga memungkinkan seseorang terjadinya perubahan perilaku yang relative tetap baik dalam berpikir, merasa, maupun dalam bertindak". Belajar adalah sesuatu yang tampak sebagai terjadinya perubahan tingkahlaku pada diri seseorang, yang dapat diamati dan diukur dalam bentuk perubahan pengetahuan (kognitif), sikap (afektif) dan keterampilan (psikomotor), ketiga hal ini berupa penilaian akhir dari proses-proses dan pemberian-pemberian yang telah disampaikan berulang-ulang, yang akan disimpan dalam waktu lama, untuk diterapkan dalamkehidupan
Gorga : Jurnal Seni Rupa

Volume 09 Nomor 01 Januari-Juni 2020

p-ISSN: 2301-5942 | e-ISSN: 2580-2380

sehari-hari, sehingga mencapai hasil belajar yang diinginkan, (Mesra, 2016:305).

Belajar merupakan rangkaian kegiatan atau aktivitas yang dilakukan secara sadar oleh seorang dan mengakibatkan perubahan dalam dirinya berupa penambahan pengetahuan atau kemahiran berdasarkan alat indera dan pengalamannya (Darmadi, 2017: 1).

Belajar tidak lepas dengan apa yang disebut Literasi, dimana Literasi dipahami lebih dari sekedar membaca dan menulis, namun mencakup keterampilan berfikir menggunakansumber-sumber pengetahuan dalam bentukdigita, auditori, dan visual. Visuak inilah yang s angat erat sekali kaitannya dalam pembelajaran Seni Rupa pada (SMP) Sekolah Menengah Pertama, (Harahap, 2017: 116).

Ahmad (2013: 05) hasil belajar merupakan kemampuan yang diperoleh seseorang setelah melalui kegiatan belajar. Karena belajar itu sendiri merupakan suatu proses dari seseorang yang berusaha untuk memperoleh suatu perubahan.

Hasil belajar merupakan prestasi yang dicapai setelah siswa menyelesaikan sejumlah materi pembelajaran (Sinar, 2018: 20)

Banyak cara yang dapat dilakukan untuk meningkatkan minat belajar dan hasil belajar seseorang, salah satunya yaitu media ajar yang menarik, dimana sebuah media ajar yang menarik akan membuat minat belajar seseorang tinggi dan tentunya akan mendapatkn hasil belajar yang tinggi pula, (Kartono, 2020:128).

Belajar dan hasil belajar dua hal yang tidak dapat dipisahkan, dimana dari paparan di atas maka dapat disimpulkan belajar adalah sebuah kegiatan yang dilakukan oleh seseorang secara sadar untuk mendapatkan sebuah perubahan baik dari sikap, pengetahuan, dan keterampilan. Ketiga hal ini merupakan hasil belajar dari s es eorang dari tidak baik menjadi baik dan dari tidak tahu menjadi tahu.

\section{Menggambar Flora}

Menggambar berasal dari kata gambar yang berarti coretan pensil pada kertas berbentuk tiruan barang (orang, binatang, tumbuhan, bendamatidsb). Menunut Apriyatno (2007: 1) menjelaskan bahwa menggambar adalah sebuah proses kreasi yang harus dilakukan secara intensif dan terus menerus. Menggambar merupakan wujud pengeksplorasian teknis dan gaya, penggalian gagasan dan kreativias, bahkan bisa menjadi sebuah eks presi dan aktualis asi diri. 


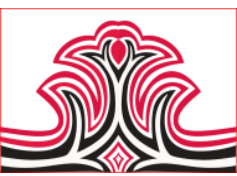

Menurut Afandi, menggambar dan melukis merupakan perwujudan bayangan angan-angan ataupun suatu pernyataan perasaan/ekspresi dan pikiran yang diinginkan. Perwujudan tersebut dapat berupa tiruan objek ataupun fantasi yang lengkap dengan garis, bidang, warna dan tekstur dengan sederhana (Saiful, 2008: 02).

Selanjutnya, menggambar lebih dikhususkan kepada menggambar bentuk, yaitu suatu kegiatan memindahkan objek model yang dlihat secara langsung, dipindahkan ke atas bidang gambar dua dimensional, yang lebih mengutamakan kemiripan terhadap model tersebut, (Mesra dalam Siregar, 2020:95)

Proses menggambar yaitu mulai dari mengamati objek, Mofit (2003: 17) dalam bukunya yang berjudul Cara mudahmenggambar mengatakan bahwa dengan pengamatan kita dapat menghasilkan bentuk seperti yang terdapat pada alam beserta faktor-faktor yang menyertainya seperti misalkan cuaca dan kondisi suatu daerah. Membuat pola dasar, melakukan pembentukan, pewarnaan gambar, dan terakhir adalah pendetailan.

Berlandas kan paparan tentang defenisi meng gambar di atas maka menggambar dapat diartikan sebagai goresan benda runcing yang dapat menimbulkan bekas atau tanda ke atas bidang datar dua dimensional, yang merupakan hasil dari perwujudan angan-angan ataupun perasaan ekspresi diri dalam bentuk bidang yang bermakna atau tidak bermakna.

\section{METODE PENELITIAN}

Metode Penelitian yang digunakan dalam penelitian ini adalah kualitatif deskriptif yang digunakan untuk mengolah data awal dan menganalisis keadaan kelas untuk menemukan sample karya menggambar flora berbentuk pohon.

Mengumpulkan data dalam penelitian dilakukan dengan teknik tes yaitu berupa Pretest dan Posttest. Jenis tes yang dipakai adalah tes kemampuan menggambar flora berbentuk pohon.

\section{HASIL DAN PEMBAHASAN}

1.Hasil

1). Karya 1 (Pretest)
Gorga : Jurnal Seni Rupa

Volume 09 Nomor 01 Januari-Juni 2020

p-ISSN: 2301-5942 | e-ISSN: 2580-2380

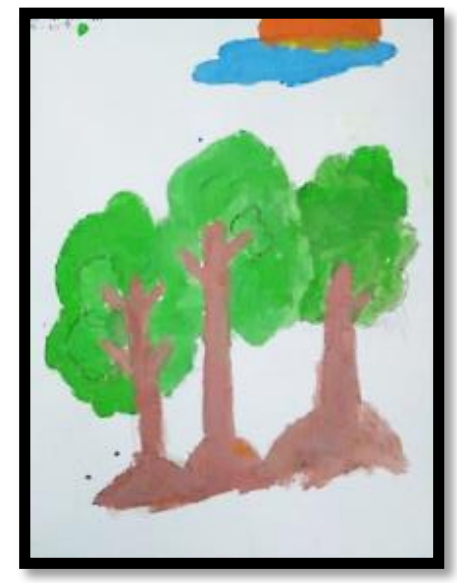

Gambar 1. Karya Siswa Tia Kartika (Sumber: Juwita Sari, 2019)

\section{2). Karya 2 (Posttest)}

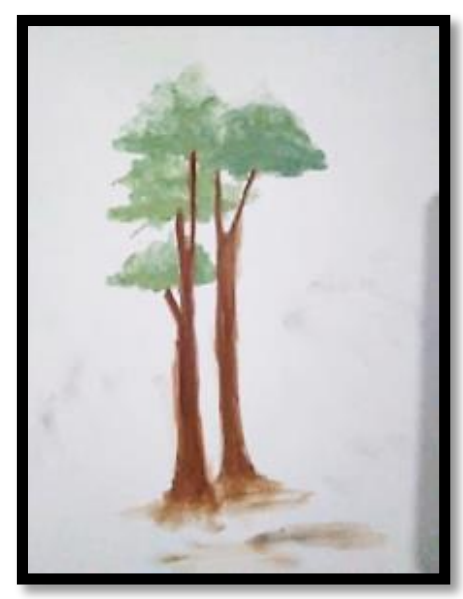

Gambar 2. Karya Siswa Tia Kartika (Sumber: Juwita Sari, 2019)

Berdasarkan gambar diatas, yaitu karya Pretest dan Posttest yang diberi penguasaan prinsip dan unsur s eni rupa memiliki perbedaan yang signifikan. Karya Posttest jauh lebih baik dibandingkan dengan karya Pretestnya, hal ini dikarenakan pada karya Posttest siswa sudah mampu menerapkan prinsip dan unsur seni rupa. Sehingga karya tampak jauh lebih baik. Contohnya, seperti karya Posttest terlihat jauh lebih baik bentuknya dibandingkan dengan bentuk karya Pretest, proporsi, gelap terang dan karakter objekjuga sudah nampak pada karya Posttest. Dalam pewarnaan dengan menggunakan watercolor pada karya Pretest lebih plakat, tidak dapat memunculkan kesan gelap terang, lebih terlihat datar (flat),. Sedangkan pada karya Posttest, pewarnaan tidak terlalu plakat dan dapat memunculkan gelap terang walaupun tidak begitu jelas. Dengan memperoleh nilai rata-rata Pretest 63 dan nilai rata-rata Posttest 78. 


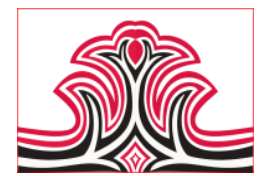

3). Karya 3 (Pretest)

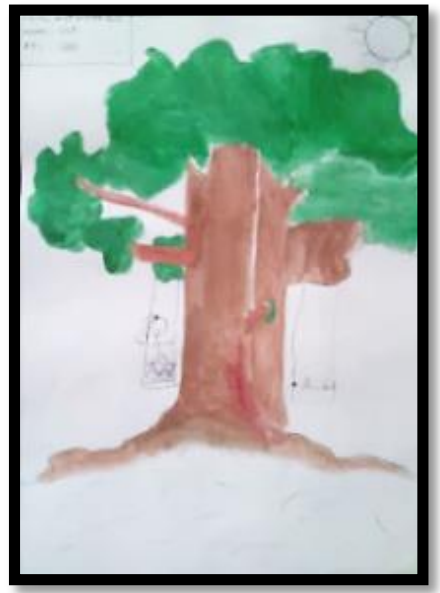

Gambar 3. Karya Siswa Muhammad Andre R. (Sumber: Juwita Sari, 2019)

\section{4). Karya 4 (Posttest)}

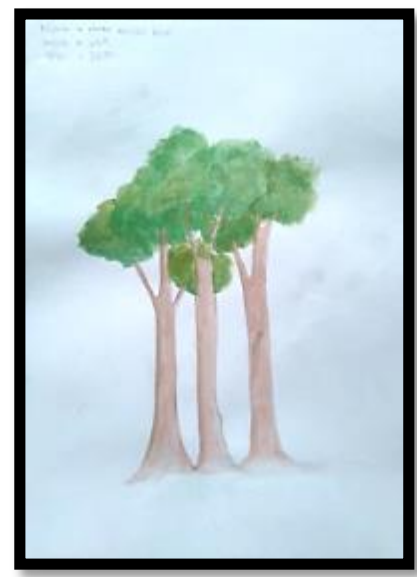

Gambar 4. Karya Siswa Muhammad Andre R. (Sumber: Juwita Sari, 2019)

Berdasarkan gambar diatas, yaitu hasil Pretest dan Posttest pada kelas kontrol tampak berbeda. Karya Posttest lebih baik dibandingkan karya Pretest dengan penguasaan prinsip dan unsur seni rupa. Hal ini dikarenakan pada karya Posttest sis wa sudah mampu menerapkan beberapa prinsip dan unsur seni rupa. Bentuk karya Posttest sudah lebih presisi dibandingkan karya Pretest, pewarnaan juga lebih terlihat rapi kary a Posttest. Jika dibandingkan dengan karya Pretest, proporsi karya Posttest jauh lebih baik yaitu perbandingan objek dengan media kertas. Pada karya Pretest perbandingan objek terlalu besar dan lebih dominan berada di bagian atas. Dengan memperoleh nilai rata-rata Pretest 75 dan nilai ratarata Posttest 79.
Gorga : Jurnal Seni Rupa

Volume 09 Nomor 01 Januari-Juni 2020

p-ISSN: 2301-5942 | e-ISSN: 2580-2380

\section{5). Karya 5 (Pretest)}

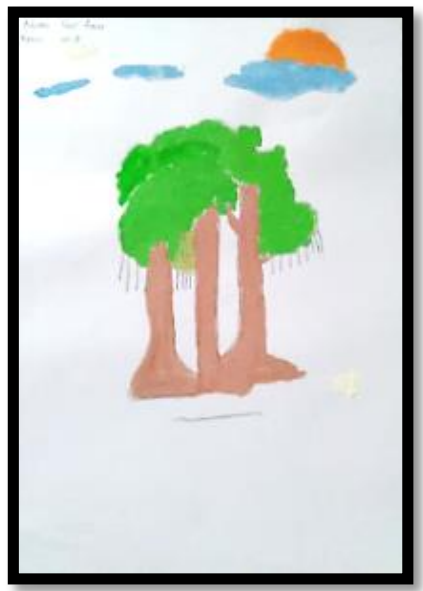

Gambar 5. Karya Siswa Anisa Br. Siahaan. (Sumber: Juwita Sari, 2019)

\section{6). Karya 6 (Posttest)}

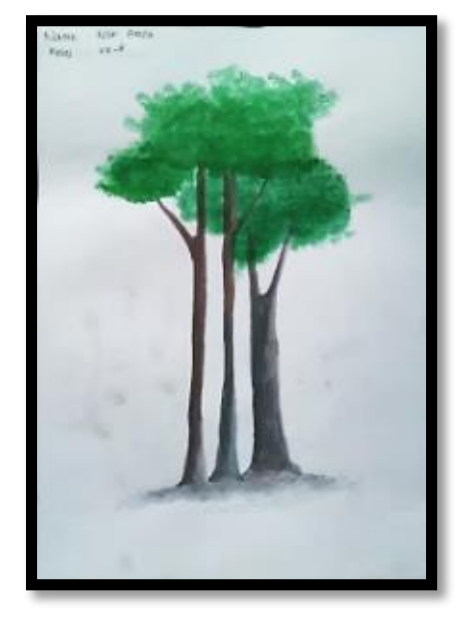

Gambar 6. Karya Siswa Anisa Br. Siahaan. (Sumber: Juwita Sari, 2019)

Berdasarkan gambar diatas, yaitu karya Pretest dan Posttest y ang diberi penguasaan prinsip dan unsur seni rupa memiliki perbedaan yang signifikan. Karya Posttest jauh lebih baik dibandingkan dengan karya Pretestnya, hal ini dikarenakan pada karya Posttest sis wa sudah mampu menerapkan prinsip dan unsur seni rupa. Sehingga karya tampak jauh lebih baik. Contohnya, seperti karya Posttest bentuk lebih ideal dan lebih presisidengan objek. Proporsi antara objek dengan media gambar padakarya Pretest cenderung berada diposisi atas, sedangkan pada karya Posttest proporsi sudah baik. gelap terang dan karakter objek juga sudah nampak pada karya Posttest sedangkan pada karya Pretest warna terlihat datar karna tidak terdapat gelap terang. Dalam pewarnaan dengan menggunakan watercolor pada karya Pretest lebih plakat, tidak dapat memunculkan kesan gelap terang, lebih terlihat datar (flat), Sedangkan pada karya Posttest, pewarnaan tidak terlalu plakat dan dapat 


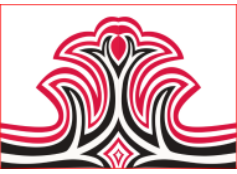

memunculkan gelap terang walaupun tidak begitu jelas. Dengan memperoleh nilai rata-rata Pretest 64 dan nilai rata-rata Posttest 80

Dilihat dari 3 karya diatas, terlihat sangat signifikan pengaruh penguasaan prinsip dan unsur seni rupa terhadap hasil karya menggambar pohon. Jika siswa dapat berlatih untuk terus menerapkannya, maka hasil akan jauh lebih baik lagi. Dan peran guru dalam proses belajar menggambar ini sangatlah penting dengan mendemonstrasikannya didepan kelas, karna dapat membantu siswa lebih cepat memahami dengan melihat langsung.

\section{Pembahas an}

Sesuai dengan indikator penilaian yang telah ditentukan, dari ke-3 karya siswa yang telah dikumpulkan yaitu Pretest dan Posttest dapat dilihat beberapa perbandingan nilai rata-rata yang begitu cukup signifikan. Karya Tia dengan nilai rata-rata Pretest 63 dan Posttest 78. Karya Muhammad Andre dengan nilai rata-rata Pretest 75 dan Posttest 79. Karya Nur Anis a dengan nilairata-rata 64 dan Posttest 80.

Dilihat dari 3 karya Posttest siswa yang telah diterapkan prinsip dan unsur seni rupa, kendala yang tampak pada karya yaitu dalam penerapan gelap terang, sis wabelum sepenuhnya dapat mengatur arah cahaya dengan konsisten. Dan jika dibandingkan dengan karya Pretest, karya Posttest jauh lebih baik.

\section{KESIMPULAN DAN SARAN}

\section{Kesimpulan}

Jika dilihat dari hasil nilai karya pretest dan posttest ke-3 siswa, terdapat peningkatan nilai rata-rata yang cukup signifikan. Dimulai dari Tia dengan nilai ratarata pretest 63 dan posttest 78. Muhammad Andre dengan nilai rata-rata pretest 75 dan posttest 79 . Nur Anisa deng an nilai rata-rata pretest 64 dan posttest 80 . Penigkatan nilai yang tampak sangat signifikan yaitu Nur anis a dengan nilai rata-rata pretest 64 menjadi 80 nilai rata-rata posttest.

Maka dapat disimpulkan bahwa dengan menerapkan prinsip dan unsur seni rupa dapat berpengaruh terhadap hasil karya siswa menjadi lebih baik dan ideal.

\section{Saran}

Bagi guru, dalam pelajaran seni rupa terkhususnya dalam menggambar, tidak hany a menggambar pohon melainkan menggambar lainnyaju ga guru diharapkan dapat menerapkan prinsip dan unsur seni rupa dengan
Gorga : Jurnal Seni Rupa

Volume 09 Nomor 01 Januari-Juni 2020

p-ISSN: 2301-5942 | e-ISSN: 2580-2380

cara mendemonstrasikannya langsung dipapan tulis atau di depan sis wa bagaimana cara atau langkahlangkah yang baik dalam menggambar tentunya dengan penerapan prinsip dan unsur seni rupa agar siswa lebih mudah memahami.

Bagi Siswa, diharapkan untuk lebih sering berlatih dalam menggambar dengan menerapkan prinsip dan unsur senirupaagar dapat menghasilkan karya yang lebih baik dan lebih ideal.

\section{DAFTAR RUJUKAN}

Ahmad, S. (2013). Teori Belajar \& Pembelajaran di Sekolah Dasar. Prenada Group: Jakarta.

Apriyatno, Very. (2007). Cara Mudah Menggambar Dengan Pensil. Jakarta: PT Kawan Pustaka.

Darmadi. (2017). Pengembangan Model Dan Metode Pembelajaran Dalam Dinamika Belajar Siswa. Yogyakarta: Deepublish.

Harahap, M.H., Fais al, F., Hasibuan, N. i., Nugrahaningsih, R. H. D., \& Azis, A. C. K. (2017). Pengembangan Program Literasi Sekolah untuk Meningkatkan Kualitas Pendidikan Dasar Tingkat Sekolah Menengah Pertama Negeri di Kota Medan. Jurnal Pembangun Perkotaan, 5(2), 115-128.

Kartono, G., Mesra, M., \& Azis, A. C. K.

Pengembangan Media Ajar Grafis Komputer Materi WPAP dalam Bentuk E-book dan Video Tutorial bagi Mahasiswa Seni Rupa. Gorga: Jurnal Seni Rupa, 9(1), 127132.

Mofit. (2003). Cara Mudah Menggambar. Jakarta: PT Gramedia Pustaka Utama.

Mesra, M., Azis, A. C. K., \& Astuti, W. W. (2016). Kontribusi Motivasi Belajar Dan Lingkungan Tempat Tinggal Terhadap Hasil Belajar Mahasiswa Jurusan Seni Rupa Universitas Negeri Medan. Jurnal Bahas Unimed, 27(3), 302-319.

Saiful, Haq. (2008). Jurus-jurus Menggambar \& Mewarnai dari Nol. Yogyakarta: Mitra Barokah Abadi Press.

Siregar, N. H., Azis, A. C. K., Mesra, M., \& Mirwa, T. (2020). Analisis Gambar Bentuk Bunga Anggrek dengan Teknik Pointilis Berwarna di SMP Al-Fityan School Medan. Gorga: Jurnal Seni Rupa, 9(1), 94-99.

Sinar. (2018). Metode Active Learning Upaya peningkatan Keaktifan Dan Hasil Belajar Siswa. Yogyakarta: Deepublish. 